\title{
Konstruksi Sosial Masyarakat Namlea atas Pola Hidup Bertoleransi Antara Umat Beragama
}

\author{
La Husni Buton ${ }^{1}$, Susiati ${ }^{*}$, Taufik ${ }^{1}$ \\ 1 Universitas lqra Buru, Indonesia \\ "Korespondensi: susiatiuniqbu@gmail.com
}

\begin{tabular}{c}
\hline Info Artikel \\
\hline Diterima 30 \\
Oktober 2021 \\
Disetujui 18 \\
November 2021 \\
Dipublikasikan 29 \\
November 2021 \\
\hline Keywords: \\
Konstruksi, Sosial, \\
Toleransi, Agama, \\
Namlea \\
\hline
\end{tabular}

(C) 2021 The Author(s): This is an open-access article distributed under the terms of

the Creative

Commons

Attribution

ShareAlike (CC BY-

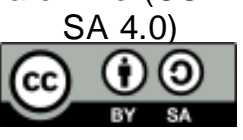

\section{Abstrak}

Tujuan penelitian ini adalah 1) mengidentifikasi proses konstruksi sosial masyarakat Namlea terhadap pola hidup bertoleransi antara umat beragama dan 2) mengidentifikasi faktor-faktor yang memengaruhi munculnya konstruksi sosial masyarakat Namlea terhadap pola hidup bertoleransi antara umat beragama. Jenis penelitian ini adalah deskriptif kualitatif dengan pendekatan fenomenologis. Data diperoleh dari data primer dan data sekunder. Hasil penelitian menunjukkan bahwa proses konstruksi sosial masyarakat Namlea terhadap cara hidup bertoleransi antarumat beragama berpegang pada teori konstruksi sosial Peter $L$. Berger, yakni dibagi menjadi dua tahapan, antara lain sosialisasi primer dan sosialisasi sekunder. Pada tahap sosialisasi primer, yang memegang peranan penting dalam memberikan pembelajaran serta menginternalisasikan cara hidup dan sikap bertoleransi antarumat beragama kepada anggota keluarga adalah orang tua yang dituakan dalam rumah tangga. Proses konstruksi sosial secara sekunder melalui pembelajaran di lingkungan masyarakat, baik itu melalui sekolah formal maupun melalui tetua adat, tokoh agama dan lain-lain. Kaitannya dengan sikap dan cara hidup bertoleransi antarumat beragama, maka dalam ketetapan adatpun masyarakat dituntut untuk saling menghargai, menghormati, menerima perbedaan baik itu agama, suku, maupun adat tradisi. Adapun faktor-faktor yang memengaruhi munculnya konstruksi sosial terhadap cara hidup bertolansi antarumat beragama pada masyarakat Namlea, yakni budaya, pendidikan, sosial kemasyarakatan, ekonomi, dan agama.

\section{Abstract}

The aims of this study are 1) to identify the social construction process of the Namlea community towards a tolerant lifestyle between religious communities and 2) to identify the factors that influence the emergence of the Namlea community's social construction towards a tolerant lifestyle among religious people. This type of research is descriptive qualitative with a phenomenological approach. Data obtained from primary data and secondary data.

The results showed that the social construction process of the Namlea community towards a tolerant way of life among religious believers adhered to Peter L. Berger's social construction theory, which was divided into two stages, namely primary socialization and secondary socialization. At the primary socialization stage, those who play an important role in providing learning and internalizing the way of life and tolerance among religious people to family members are parents who are elders in the 
household. The process of secondary social construction is through learning in the community, either through formal schools or through traditional elders, religious leaders and others. In relation to the tolerant attitude and way of life among religious people, even in customary provisions, the community is required to respect each other, respect, accept differences, be it religion, ethnicity, or traditional customs. The factors that influence the emergence of social construction on the way of life of inter-religious tolerance in the Namlea community, namely culture, education, social society, economy, and religion.

\section{Pendahuluan}

Indonesia merupakan bangsa yang terdiri dari beragam suku, keyakinan, dan budaya yang heterogen. Keberagaman tersebut merupakan sesuatu yang lazim terjadi. Adanya keberagaman serta perbedaan agama di tengah-tengah masyarakat, sangat diperlukan, ditumbuhkan serta diciptakan pola hidup bertoleransi agar dapat menunjang kemaslahatan kehidupan dan interaksi sosial antarmasyarakat. Sebaliknya, jika pola hidup bertoleransi antarumat beragama tidak ditu mbuhkan, maka kemungkinan masalah atau konflik sosial yang berkaitan dengan agama akan banyak terjadi di sekitar kita.

Kabupaten Buru merupakan Kabupaten yang berada di Provinsi Maluku. Kabupaten Buru terdapat berbagai ragam etnis, suku, agama, dan budaya. Keragaman tersebut tercipta dengan harmonis antarmasyarakat yang satu dengan masyarakat yang lain. Ada beberapa daerah yang di dalamnya didominasi oleh pemeluk agama Kristen, Katolik dan adapula di beberapa daerah yang dominan agama Islam. Salah satu hal yang diinginkan oleh Masyarakat Pulau Buru dalam menciptakan kenyamanan dalam masyarakat salah satunya terciptanya hidup saling berdampingan antarmasyarakat meskipun dalam realitas sosial yang multiagama dan multikultural.

Hal tersebut, bisa saja terjadi sebab pengalaman intersubyektif dan obyektif masyarakat terhadap cara pandang hidup bertoleransi antarumat beragama telah lama terjalin dan tercipta di lingkungan masyarakat Pulau Buru secara umum dan pada masyarakat Desa Namlea pada khususnya.

Konstruksi sosial terhadap realitas sosial (Social Construction of Reality) dimaksudkan sebagai suatu rangkaian sosial lewat perilaku atau aktifitas serta hubungan berinteraksi baik antarperorangan maupun kelompok yang diterapkan secara berkesinambungan pada keadaan atau realita yang berlaku dan dirasakan bersama-sama secara subyektif. Konstruksi sosial juga merupakan teori yang berdasar pada pandangan konstruktivisme di mana teori berpendapat bahwa masyarakat dikatakan manusia bebas jika konstruksi sosialnya diciptakan pertama oleh pribadi sendiri. Suatu kehendak yang muncul dalam diri pribadi seseorang dapat menjadi penentu dalam lingkungan sosial karena banyak hal yang dimiliki salah satunya masalah kebebasan dalam bertindak di luar sistem, struktur serta pranata sosialnya. Manusia sebagai pencipta sebuah realitas sosial yang relatif bebas di lingkungan sosialnya, jika dilihat dari proses sosialnya (Rahman, 2019; Sahib, et. al., 2019).

Di Maluku sendiri pernah terjadi kerusuhan tahun 1999-2001 yang manyangkut polemik agama yang pusatnya berada di Kota Ambon dan menyebar ke beberapa wilayah di Maluku termasuk di Pulau Buru. Hal itu menyisakan luka di hati masyarakat baik masyarakat yang muslim maupun umat Kristiani. Dari semua 
kejadian itu, sekarang masyarakat hidup damai berdampingan dalam satu kesatuan yang berlandaskan Pancasila. Menariknya, serangkaian ketegangan ataupun pertentangan sosial yang pernah terjadi dulu, masyarakat tidak berlarut dan tidak terpengaruh terhadap kehidupan sosial masyarakat yang ada di Desa Namlea. Hal tersebut dapat terjadi sebab masyarakat menciptakan dan mewujudkan pola hidup bertoleransi antarumat beragama dalam lingkungan sosial sehari-hari yang didasari oleh prinsip kemajemukan atau plu ralisme.

Penelitian ini merujuk pada beberapa penelitian terdahulu, yakni Arifuddin Ismail (2010) dengan judul Refleksi Pola Kerukunan Umat Beragama yang Berfokus pada Fenomena Keagamaan di Jawa Tengah, Bali, dan Kalimantan Barat. Hasil penelitian membuktikan bahwa kerukunan umat beragama dimungkinkan akan terwujud apabila agama diberikan kesempatan dalam ruang buat berdialog bersamaan dalam ruang budaya tanpa terdapat unsur paksaan berdasarkan pihak lain (Saleh, et al., 2021). Dengan berdialog, kerukunan beragama tampak konkret melalui peningkatan pemahaman ajaran agama dalam tiap-tiap umat beragama, menjunjung tinggi disparitas dan keragaman pemikiran keagamaan, mengesampingkan berbagai pikiran yg menduga pendekatan buday a tidak nemiliki hubungan erat. Melalui dialog tersebut, juga akan tercipta kedewasaan beragama, yakni mampu menghormati dan menghargai disparitas keyakinan dalam beragama (Ismail, 2010).

Ujang Mahadi (2013) dengan judul "Membangun Kerukunan bersosial masyarakat yang berada dalam beda kepercayaan atau beda agama di Desa Talang Benuang. Kerukunan di Desa Talang Benuang terwujud dari adanya hubungan sosial, terbangunnya komunikasi yang selaras, saling toleransi, menghargai, menghormati, dan meminimalisasi perasaan singgung- menyinggung terkait agama dalam kehidupan masyarakat sehari-hari. Selain itu, ada beberapa faktor lain yang mendukung kerukunan Desa Talang Benuang, yakni terwu ju dnya kesadaran yang tinggi dari tiap diri masyarakat terhadap pentingnya hidup rukun beragama yang turun temu run telah terbangun sejak dulu dari para nenek moyang, tertanamnya jiwa kebangsaan atau nasionalisme pada diri warga dalam kehidupan sosial masyarakat, adanya ikatan kekeluargaan yang didapatkan dari perkawinan beda agama (Mahadi, 2013).

Suhasran (2018) dengan judul "Pola Kerukunan Umat Beragama di Kabuapten Soppeng" dengan berfokus pada keadaan real kehidupan, pola kerukunan, dan pendukung kerukunan dan keselarasan umat beragama di Kabupaten Soppeng. Hasil penelitian membuktikan bahwa fenomena konkret hidup bermasyarakat antarumat beragama di Kabupaten Soppeng terlihat dari adanya saling toleransi dalam hal kerja sama dalam tiap kegiatan atau kerja bakti di lingkungan masyarakat. Adapun bentuk kerja sama masyarakat di Kabupaten Soppeng dalam menciptakan kerukunan yang umum dilakukan misalnya menggiatkan musyawarah atau pertemuan antartokoh agama dengan tujuan untuk berdialog terkait peningkatan keharmonisan, keselarasan, keseimbangan, serta kerukunan antarumat beragama, serta terciptanya kerukunan masyarakat yang beda agama di Kabupaten Soppeng dilatarbelakangi oleh terwujudnya saling menghormati, saling menghargai satu sama lain, sehingga komunikasi yang terjalin antarmasyarakat membawa pemikiran yang positif. Dengan pemikiran yang positif kehidupan bersosial menjadi lebih aman, tenteram, nyaman, serta jauh dari kesalahpamahan (Suhasran, 2018). 
Sementara, penelitian ini mengangkat masalah tentang bentuk konstruksi sosial masyarakat Namlea terhadap pola hidup bertoleransi antara umat beragama. Dalam penelitian ini lebih berfokus pada bentuk-bentuk kostruksHi sosial masyarakat Namlea dalam mempola gaya hidup bertoleransi atara umat beragama serta faktor-faktor munculnya kostruksi sosial masyarakat Namlea dalam mempola gaya hidup bertoleransi atara umat beragama.

Berdasarkan penjelasan masalah di atas, maka penelitian ini bertujuan untuk 1) mengidentifikasi proses konstruksi sosial masyarakat Namlea terhadap cara hidup bertoleransi antarumat beragama dan 2) mengidentifikasi faktor-faktor yang memengaruhi munculnya konstruksi sosial terhadap cara hidup bertolansi antarumat beragama pada masyarakat Namlea.

\section{Konstruksi Sosial}

Konstruksi sosial adalah teori sosiologi kontemporer, dipelopori oleh Peter L. Berger dan Thomas Luckmann. Teori ini adalah sebuah pendekatan teoretis dan sistematis tentang sosiologi pengetahuan (penalaran teoretis yang sistematis), bukanlah sebuah kajian historis tentang perkembangan disiplin ilmu. Pemikiran Berger dan Luckmann dilandasi pula oleh pemikiran sosiologi lain, misalnya Schutzian mengenai fenomenologi, Weberian mengenai berbagai makna subjektif, Durkhemian-Parsonian terkait struktur, pemikiran Marxian mengenai dialektika, dan pemikiran Herbert Mead mengenai hubungan simbolik (Peter $L$ Berger \& Luckmann, 1990).

Teori konstruksi sosial yang dipelopori oleh P.L. Berger, (1994) mengungkapkan, bahwa agama merupakan bagian dari kebudayaan berasal dari tata pola konstruksi sosial masyarakat atau manusia. Maksdunya, ditemukannya proses dialektika antarmasyarakat dengan agama. Agama adalah entitas objektif, yakni karena agama berada di luar diri manusia yang akan merasakan suatu proses objektivasi seoperti halnya saat agama berdiri dalam tata norma (kebiasaan) dan teks. Suatu kebiasaan atau norma serta teks yang dimaksud kemudian akan mengalami proses internalisasi dalam diri pribadi masyarakat. Hal tersebut berlaku sebab adanya pemaknaan oleh masyarakat untuk menjadi pedoman hidup (way of life/guidance). Selain itu, agama juga mengalami proses ekternalisasi. Hal ini disebabkan agama menjadi sesuatu shared di masyarakat. Dalam teori konstruksi sosial dinyatakan bahwa masyarakat yang hidup dalam situasi sosial tertentu dominan melakukan proses hubungan atau interaksi secara simultan pada lingkungannya.

\section{Interaksi dan Realitas Sosial}

Gillin dan Gillin, dalam (Tuasalamony et al., 2020), interaksi sosial merupakan berbagai hubungan sosial yang berubah-ubah (dinamis), mengenai ikatan antarindividu dengan individu yang lain, antarkelompok dengan kelompok maupun antarindividu dengan kelompok. Gambaran lain dijlaskan pula oleh Macionis, yakni interaksi sosial adalah suatu proses yang mana masyarakatmasyarakat berinteraksi satu dengan yang lain dalam sebuah hubungan atau relasi.

Realitas sosial (social reality) merupakan realitas yang bentuk secara sosial, maksudnya suatu keadaan yang timbul dari pemikiran manusia dan berkembang menjadi nyata lewat kebiasaan, hubungan timbal balik (interaksi), serta konsensus. 
Selain itu, dalam ilmu sosiologi, realitas sosial juga disebut dengan suatu keadaan real yang terjadi dalam kehidupan bermasyarakat, bersosial, dan bernegara yang terbentuk dari hasil konstruksi sosial.

Berger dan Luckmann menyebut (dalam Tuasalamony et al., 2020) mengemukakan bahwa ada tiga tahapan pembentukan kostruksi sosial, yakni

1) Eksternalisasi, yakni suatu proses berbagai macam ide atau gagasan yang timbul dari pemikiran manusia dan menjadi sebuah hal yang menonjol di luar pribadi atau diri individu. Keberadaan gagasan atau ide tersebut sudah ada dalam suatu struktur sosial.

2) Objektifikasi, yaitu suatu proses gagasan-gagasan yang dijadikan sebagai objek dan mulai diinterpretasikan menjadi suatu yang nyata. Objektifikasi ini melibatkan tiga hal, yakni interaksi, konsensus, serta habituasi.

3) Internalisasi adalah suatu proses yang mana keadaan real/nyata terhadap suatu objek yang sudah mengalami proses objektifikasi, setelah itu diserap masuk ke dalam diri individu manusia sebagai suatu pengetahuan.

\section{Toleransi}

Pengetian toleransi secara etimologi berasal dari bahasa Latin, yaitu tolerance yang bermakna menahan diri. Sedangkan, pengertian toleransi secara terminologi, yakni suatu tata laku atau sikap saling menghormati, menghargai, memberikan kebebasan dalam berpendapat, kebebasan pandangan, serta saling percaya antarsesama masyarakat meskipun berada pada situasi beda agama, suku, dan budaya (Quthub, 1991).

Menurut (Bastanuddin, 2005) menyatakan bahwa agama memperkuat ikatan solidaritas dan toleransi beragama dalam tatanan sosial. Bustanuddin juga mengatakan bahwa agama adalah sebagai pemicu konflik dan perpecahan kehidupan manusia.

\section{Metode}

\subsection{Jenis Penelitian}

Jenis penelitian ini adalah deskriptif kualitatif, yakni mengupas berbagai hal yang berhubungan dengan fenomena sosial dan berbagai gejala sosial yang berfokus pada konstruksi sosial atas cara hidup bertoleransi antarumat beragama, sehingga penelitian ini memakai pendekatan fenomenologi. Pendekatan fenomenologi, yakni suatu pemahaman tentang bagaimana dan seperti apa du nia kehidupan intersubyektif masyarakat suatu daerah yang diteliti.

Salah satu tujuan umum pendekatan fenomenologi adalah untuk membangun pemaknaan umum terkait tata laku atau tindakan sosial yang berlaku di tengah tengah masyarakat (Fatimah et al., 2021). Selain itu, pendekatan fenomenologi dapat merekontruksi kembali turunan interpretasi (makna yang digunakan saat berikutnya) dari tindakan yang bermakna pada komunikasi intersubjektif individu dalam dunia kehidupan sosial. Cara kerja pendekatan fenomenologi terhadap permasalahan dalam penelitian ini, yakni mendeskripsikan dan menginterpretasi konstruksi sosial masyarakat atas gaya atau cara hidup bertoleransi antarumat beragama di Desa Namlea. 


\section{Data dan Sumber Data}

Data dalam penelitian ini diperoleh dari data primer dan data sekunder. Data primer diperoleh langsung dari sumber aslinya, yaitu dengan menggunakan teknik observasi langsung dan wawancara mendalam. Sedangkan, data sekunder berasal dari dokumen di beberapa kantor Desa di Kota Namlea yang menjadi tempat penelitian.

Sumber data penelitian ini diambil dari beberapa informan, yakni tokoh masyarakat dan para pemuka agama sedangkan untuk mendapatkan data yang akurat, peneliti menggunakan pengecekan keabsahan data menggunakan triangulasi sumber dan metode. Triangulasi digunakan sebagai teknik untuk mengecek keabsahan data. Moleong (dalam Buton et al., 2020), triangulasi adalah teknik pemeriksaan keabsahan data yang memanfaatkan sesuatu yang lain dalam membandingkan hasil wawancara terhadap objek penelitian (Moloeng, 2010). Tempat yang dipilih sebagai lokasi penelitian adalah Kota Namlea, Kabupaten Buru.

\subsection{Metode dan Teknik Pengumpulan Data}

Metode pengumpulan data dalam penelitian ini adalah metode observasi. Kartono (dalam Masniati et al., 2021), observasi adalah studi yang disengaja dan sistematis tentang fenomena sosial dan gejala-gejala psikis dengan jalan pengamatan dan pencatatan

Metode ini digunakan untuk mendapatkan data lisan atau tertulis, yakni berupa konstruksi sosial masyarakat atas cara hidup bertoleransi antarumat beragama di Kota Namlea. Teknik-teknik yang digunakan untuk melengkapi metode observasi tersebut, yaitu survey lapangan (field study), wawancara (interview), studi dokumentasi, dan studi literatur.

\subsection{Penganalisisan Data}

Penelitian ini adalah peneltian kualitatif. Penelitian kualitatif menyajikan hasil penelitiannya secara deskriptif kualitatif yang akan melihat dan mengidentifikasi potensi dan strategi melalui wawancara secara mendalam dengan para narasumber. Untuk menganalisis data yang diperoleh menggunakan langkahlangkah sebagai berikut pereduksian data, penyajian data, verifikasi data, dan analisis data.

\section{Hasil dan Pembahasan}

Adapun pembahasan dalam penelitian mencakup dua permasalahan, yakni 1) mengidentifikasi proses konstruksi sosial masyarakat Namlea terhadap cara hidup bertoleransi antarumat beragama dan 2) mengidentifikasi faktor-faktor yang memengaruhi munculnya konstruksi sosial terhadap cara hidup bertolansi antarumat beragama pada masyarakat Namlea.

\subsection{Proses Konstruksi Sosial Masyarakat Namlea Terhadap Cara Hidup Bertoleransi Antarumat Beragama}

Hubungan antara masyarakat di Desa Namlea sangatlah erat baik dilihat dari berbagai sisi kemasyarakatan. Kemampuan yang dimiliki oleh masyarakat Desa Namlea dalam hidup berdampingan di masyarakat yang pluralisme baik dari segi suku maupun agama secara langsung merupakan realitas sosial di Desa Namlea. 
Hubungan harmonis yang terjalin antramasyarakat baik yang berasal dari beragam suku ataupun agama ini tidak terlepas dari proses konstruksi sosial yang lahir secara alamiah dari diri masyarakat Desa Namlea.

Perlu diketahui masyarakat Desa Namlea terdiri dari berbagai suku, seperti suku Bugis-Makassar, suku Jawa, suku Sunda, suku Buton, suku asli masyarakat Pulau Buru serta terdiri pula dari berbagai agama seperti Islam, Katolik, dan Protestan. Tentu keberagaman ini berdampak pada cara pandang, ideologi, serta persepsi-persepsi yang berbeda. Namun dengan konstruksi sosial di tengahtengah masyarakat menjadikan sikap dan cara hidup bertoleransi antarmasyarakat yang berbeda agama khususnya menjadi suatu realitas subyektif dan realitas obyektif.

Penelitian ini berpegang pada teori konstruksi sosial Peter L. Berger, yakni pertama-tama yang akan dianalisis dalam penelitian ini adalah momen internalisasi yang dibagi menjadi dua tahapan, antara lain sosialisasi primer dan sosialisasi sekunder. Sosialisasi primer diperankan oleh orang tua sedangkan sosialisasi sekunder diperankan oleh lingkungan di luar rumah seperti sekolah, tokoh adat, dan tokoh agama di Desa Namlea.

Dengan berdasar pada teori Peter L. Berger, diharapkan hasil penelitian ini memberikan gambaran secara fenomenologis alur atau proses konstruksi sosial masyarakat Desa Namlea terhadap cara hidup bertoleransi antarumat beragama di Desa Namlea.

\section{a. Proses Konstruksi Sosial dengan Sosialisasi Primer}

Pada tahap sosialisasi primer, yang memegang peranan penting dalam memberikan pembelajaran serta menginternalisasikan cara hidup dan sikap bertoleransi antarumat beragama kepada anggota keluarga adalah orang tua yang dituakan dalam rumah tangga. Proses internalisasi yang diterapkan dalam lingkungan keluarga di Desa Namlea didasarkan pada pengalaman-pengalaman sikap serta cara hidup yang dimilikinya selama menjalani kehidupan sosial dengan masyarakat lainnya.

Langkah awal yang ditempuh sebelum sikap dan cara hidup bertoleransi antarumat beragama terinternalisasi, anggota keluarga menerapkan internalisasi sisi subyektif keagamaan atau mereka menginternalisasikan agama yang dianutnya kepada anggota keluarga mereka sejak dini. Hal ini dilakukan untuk membentuk identitas beragama yang mereka anut. Proses internalisasi ini terlihat dalam berbagai bentuk seperti memperkenalkan dan memahami berbagai kultur atau adat tradisi yang menjadi hal penting atau karakterisitik dari tiap-tiap agama (kosmos keramat).

Langkah selanjutnya adalah habitusiasi (pembiasaan). Peran keluarga menginternalisasikan suatu pembiasaan atau habitusiasi kepada anggota keluarga untuk meningkatkan partisipasi serta intensitas mereka dalam mengikuti dan menjalankan berbagai bentuk acara dan ritual keagamaan yang dianjurkan oleh masing-masing agama. Langkah berikutnya adalah menginternalisasikan paham pluralisme. Pluralisme tidak terlepas dari fenomena multiagama yang telah memunculkan karakteristik masing-masing agama di Desa Namlea.

Setelah terinternalisasinya paham pluralisme kepada anggota keluarga, selanjutnya yang ditempuh oleh orang tua adalah menerapkan sikap dan cara 
hidup bertoleransi antarumat beragama, seperti kebebasan bersosial, ajaranajaran dari tiap kosmos keramat (agama) yang menjadi keyakinan orang tua.

Proses konstruksi sosial dengan sosialisasi primer ini membentuk pola pikir anggota keluarga ke arah yang pluralis, artinya kita tidak akan hidup tanpa adanya kosmos atau masyarakat lainnya. Meskipun berada dalam keberagaman suku, budaya, adat, serta agama tetapi rasa solid antarmasyarakat harus tetap terjaga.

\section{b. Proses Konstruksi Sosial dengan Sosialisasi Sekunder}

Proses konstruksi sosial secara sekunder melalui pembelajaran di lingkungan masyarakat, baik itu melalui sekolah formal maupun melalui tetua adat, tokoh agama dan lain-lain. Di Desa Namlea, selain tokoh agama terdapat pula tokoh adat. Hal ini dikarenakan di Pulau Buru sejak dulu merupakan daerah adat hingga sekarang. Sehingga apapun yang berkaitan dengan sosial kemasyarakatan harus tabe (permisi) kepada tetua adat. Kaitannya dengan sikap dan cara hidup bertoleransi antarumat beragama, maka dalam ketetapan adatpun masyarakat dituntut untuk saling menghargai, menghormati, menerima perbedaan baik itu agama, suku, maupun adat tradisi. Masyarakat Namlea sangatlah menghormati dan menjunjung tinggi ketetapan tetua adat atau kepala Soa (Kepala Marga). Selain itu, penginternalisasian sikap dan cara hidup bertoleransi didapat dari lingkungan masyarakat misalnya kerjasama dalam kegiatan keagamaan, kerjasama dalam kegiatan ekonomi, dan kerjasama dalam bakti sosial.

Berikut ini beberapa dokumentasi konstruksi sosial masyarakat Namlea terhadap cara bertoleransi antarumat beragama.

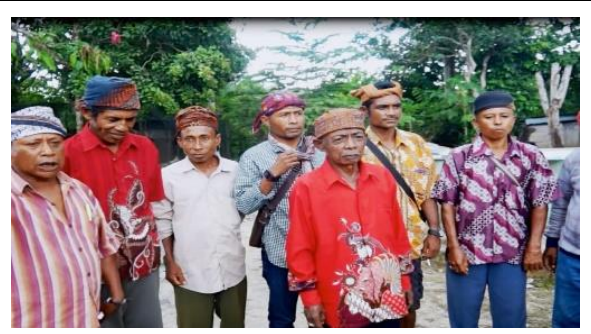

Gambar 1. Para Tetua Adat

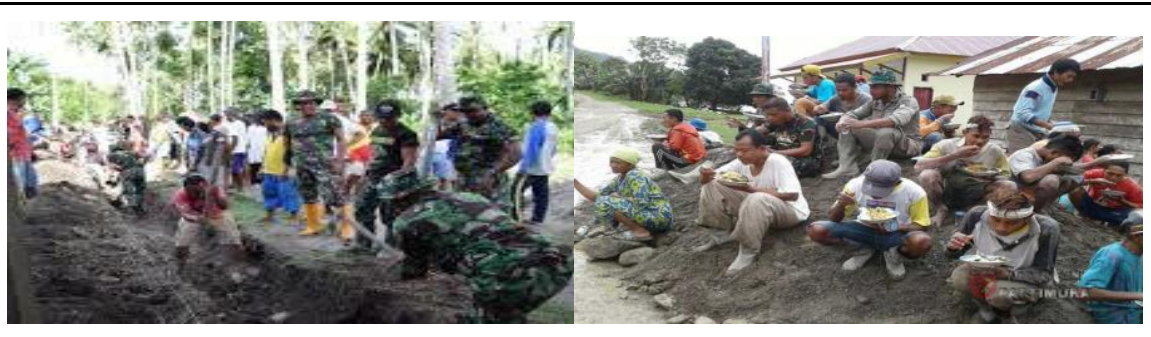

Gambar 3. Kerja Bakti Antarwarga 


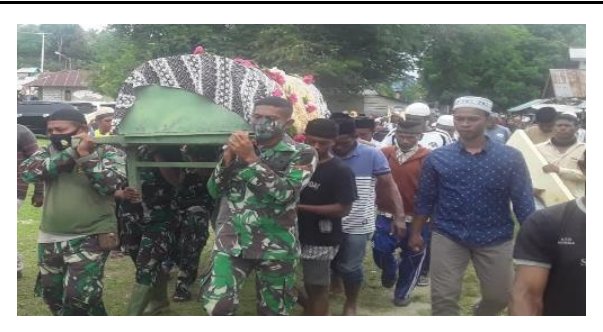

Gambar 3.. Toleransi Antarwarga

\subsection{Faktor-faktor yang mempengaruhi Munculnya Konstruksi Sosial terhadap Cara Hidup Bertoleransi Antarumat Beragama pada Masyarakat Namlea}

\section{a. Budaya}

Budaya merupakan suatu cara hidup yang berkembang dan dimiliki bersama oleh sekelompok orang, serta diwariskan dari generasi ke generasi. Budaya terbentuk dari banyak unsur yang rumit, termasuk sistem agama dan politik, adat istiadat, bahasa, perkakas, pakaian, bangunan, dan karya seni. Hidup bertoleran si masyarakat Namlea tidak terlepas dari pengaruh budaya, di mana budaya toleransi sangatlah tinggi di masyarakat, baik itu antarsuku, antaragama, antaradat, dan lain-lain.

Nilai toleransi dalam budaya terlihat ketika masyarakat melaksanakan tradisi masaurat, tradisi Lata Hawa, acara-acara perkawinan, dan lain-lain. Hal ini dilandasi karena adanya prinsip dan cerminan hidup masyarakat, salah satunya adalah hubungan kai wai. Kai bermakna kakak dan wai berarti adik, jadi kai wai disebut dengan kakak adik.

Meskipun tatanan sosial masyarakat terbangun dalam perbedaan suku, agama, pandangan, serta tradisi tetapi masyarakat secara umum telah tersosialisasi dalam bentuk kekerabatan yang hakiki, adapun sebutan-sebutan yang mencerminkan adanya kekerabatan di masyarakat seperti 'kae to yako kai wai' yang maknanya 'kamu dan aku bersaudara (kakak adik)' atau sebutan 'kita rua kai wai' yang maknanya 'kita berdua bersaudara'.

b. Pendidikan

Pendidikan merupakan pembelajaran pengetahuan, keterampilan, dan kebiasaan sekelompok orang yang diturunkan dari satu generasi ke generasi berikutnya melalui pengajaran, pelatihan, atau penelitian. Pendidikan sering terjadi di bawah bimbingan orang lain, tetapi juga memungkinkan secara otodidak. Pendidikan merupakan salah satu faktor terbentuknya kontruksi sosial masyarakat Namlea terhadap pola bertoleransi antarumat beragama di Desa Namlea.

Masyarakat Namlea rata-rata berpendidikan tinggi (hingga di Universitas) sehingga termanifestasi pemikiran dan pandangan plural terhadap cara-cara menciptakan kemakmuran, kenyamanan, kemashlahatan di tengah-tengah masyarakat. Pendidikan karakter yang diperoleh dari sekolah formal dan informal membawa dampak positif pada kehidupan masyarakat dan generasi di Desa Namlea. Meskipun Maluku pernah terjadi perpecahan antar umat beragama, tetapi dengan adanya penerapan pendidikan karakter di lingkungan keluarga dan sekolah menjadikan masyarakat Namlea mejadi manusia yang penuh rasa tenggang rasa, saling menghargai, saling menghormati antarumat beragama. 


\section{c. Sosial Kemasyarakatan}

Kegiatan sosial kemasyarakatan adalah kegiatan bersama anggota masyarakat yang bersifat sosial (tidak mencari keuntungan ekonomi) di lingkungan tempat tinggal. Mengikuti kegiatan sosial kemasyarakatan adalah partisipasi/ keikutsertaan (terlibat aktif) seseorang dalam kegiatan sosial kemasyarakatan yang ada di lingkungan tempat tinggal yang masih dalam lingkup $\mathrm{RT} / \mathrm{RW} /$ Dusun/Desa/Kelurahan.

Kegiatan-kegiatan sosial kemasyarakatan merupakan salah satu faktor yang mempengaruhi terbentuknya konstruksi sosial terhadap pola bertoleransi antarumat beragama pada masyarakat Namlea. Seperti kegiatan kerja bakti, perbaikan sarana dan prasarana peribadatan (Masjid dan Gereja), kegiatan pada upacara-upacara formal dalam pemerintahan dan lain -lain.

Masyarakat Namlea juga selalu menumbuhkan rasa solidaritas antarsesama baik itu yang berbeda suku, marga, dan agama. Hal ini terwujud karena pola pikiran dan pandangan masyarakat yang mengacu pada simbol kai wai (basudara/ bersaudara), di manapun dan siapapun, yang namanya makhluk Tuhan, tetap kita saudara.

\section{d. Ekonomi}

Ekonomi juga sangat menunjang munculnya konstruksi sosial masyarakat Namlea terhadap pola toleransi antarumat beragama di Desa Namlea. Hal ini dikarenakan fenomena tatanan sosial masyarakat yang saling tolong menolong terhadap sesama, tidak memandang perbedaan suku, marga, serta agama. Di Namlea, jika ada masyarakat yang mengalami keterbatasan ekonomi, maka masyarakat lain akan berbondong-bondong untuk membantu. Selain itu, ada juga masyarakat yang sering menawarkan lowongan pekerjaan kepada masyarakat yang membutuhkan pekerjaan.

Hal ini, tidak lain karena dari nenek moyang dahulu mereka sudah mewujudkan sikap tolong menolong kepada sesama dan tidak mempermasalahkan perbedaan-perbedaan yang ada di masyarakat.

\section{e. Agama}

Agama sangat berperan penting terhadap adanya pola toleransi antarumat beragama di Desa Namlea. Hal ini dikarenakan ajaran-ajaran dari setiap agama atau keyakinan yang mengarah pada terciptanya kenyamanan, kemakmuran, kemaslahatan manusia di muka bumi. Sikap toleransi sangatlah penting sebagai alat pemersatu bangsa. Tanpa adanya toleransi kehidupan yang penuh dengan kemajemukan dan perbedaan ini tidak akan pernah bersatu.

Toleransi (as-samahah) merupakan suatu konsep modern dalam mendeskripsikan sikap atau perilaku saling menghormati dan saling bekerjasama di antara kelompok masyarakat yang berbeda-beda baik secara suku, bahasa, marga, agama, politik, serta politik.

Masyarakat Islam di Desa Namlea memiliki pandangan bahwa konteks toleransi antarumat beragama, bahwasanya Islam memiliki konsep yang jelas yang menyatakan bahwa "Tidak ada paksaan dalam agama, bagi kalian agama kalian, dan bagi kami agama kami”. Inilah yang menjadi tombak terciptanya kemakmuran dan kenyamanan masyarakat Namlea di tenga-tengah lingkungan masyarakat. 
Dari beberapa faktor di atas menandakan bahwa konstruksi sosial masyarakat Namlea terhadap pola bertoleransi antarumat beragama sangatlah terjalin dengan baik. Peran masyarakat sebagai pelaku sosial terjalin sangat harmonis, aman, dan tenteram.

\section{Penutup}

Berdasarkan hasil penelitian dalam pembahasan sebelumnya, dapat disimpulkan beberapa hal yang menjadi temuan dalam penelitian ini terkait Proses Konstruksi Sosial Masyarakat Namlea Terhadap Cara Hidup Bertoleransi Antarumat Beragama dan Faktor-faktor yang memengaruhi Munculnya Konstruksi Sosial terhadap Cara Hidup Bertolansi Antarumat Beragama pada Masyarakat Namlea.

Proses konstruksi sosial masyarakat Namlea terhadap cara hidup bertoleransi antarumat beragama berpegang pada teori konstruksi sosial Peter L. Berger, yakni dibagi menjadi dua tahapan, antara lain sosialisasi primer dan sosialisasi sekunder. Sosialisasi primer diperankan oleh orang tua sedangkan sosialisasi sekunder diperankan oleh lingkungan di luar rumah seperti sekolah, tokoh adat, dan tokoh agama di Desa Namlea.

Pada tahap sosialisasi primer, yang memegang peranan penting dalam memberikan pembelajaran serta menginternalisasikan cara hidup dan sikap bertoleransi antarumat beragama kepada anggota keluarga adalah orang tua yang dituakan dalam rumah tangga. Proses internalisasi yang diterapkan dalam lingkungan keluarga di Desa Namlea didasarkan pada pengalaman-pengalaman sikap serta cara hidup yang dimilikinya selama menjalani kehidupan sosial dengan masyarakat lainnya.

Proses konstruksi sosial secara sekunder melalui pembelajaran di lingkungan masyarakat, baik itu melalui sekolah formal maupun melalui tetua adat, tokoh agama dan lain-lain. Di Desa Namlea, selain tokoh agama terdapat pula tokoh adat. Hal ini dikarenakan di Pulau Buru sejak dulu merupakan daerah adat hingga sekarang. Sehingga apapun yang berkaitan dengan sosial kemasyarakatan haru s tabe (permisi) kepada tetua adat. Kaitannya dengan sikap dan cara hidup bertoleransi antarumat beragama, maka dalam ketetapan adatpun masyarakat dituntut untuk saling menghargai, menghormati, menerima perbedaan baik itu agama, suku, maupun adat tradisi.

Adapun faktor-faktor yang memengaruhi munculnya konstruksi sosial terhadap cara hidup bertolansi antarumat beragama pada masyarakat Namlea, yakni budaya, pendidikan, sosial kemasyarakatan, ekonomi, dan agama.

\section{Daftar Pustaka}

Berger, P.L. (1994). Langit Suci: Agama sebagai Realitas Sosial. Pustaka LP3ES.

Berger, Peter L, \& Luckmann, T. (1990). Tafsir Sosial atas Kenyataan. LP3ES.

Buton, L. H., Susiati, S., Masniati, A., Tuasalamony, K., Hatuwe, R. S. M., Tahir, S. Z. Bin, Tenriawali, A. Y., \& Marasabessy, R. N. (2020). Membangun Ketahanan Relegius Anak Melalui Active Parental Involvement. Islam Nusantara, 04(01), 111-125.

Fatimah, F., Susiati, S., Jelira, N. F., Umanailo, C. B., \& Tahir, S. Z. Bin. (2021). 
Environmental Ethics of Kaki Air Village Community at Teluk Kaiely District, Buru Regency. ELS Journal on Interdisciplinary Studies in Humanities, 1(3), 355-362.

Ismail, A. (2010). Refleksi Pola Kerukunan Umat Beragama (Fenomena Keagamaan di Jawa Tengah, Bali dan Kalimantan Barat). Analisa, XVII(02), 175-186.

Mahadi, U. (2013). Membangun Kerukunan Masyarakat Beda Agama Melalui Interaksi Dan Komunikasi Harmoni Di Desa Talang Benuang Provinsi Bengkulu. Kajian Komunikasi, 1(1), 51-58.

Masniati, A., Susiati, S., Tuasalamony, K., Hatuwe, R. S. M., Buton, L. H., Taufik, T., Bugis, R., lye, R., \& Harziko, H. (2021). Implementasi Nilai Budaya Lokal Sebagai Pengembangan Pariwisata di Kabupaten Buru. Sang Pencerah, 7(2), 292-310.

Muhammad Quthub. (1991). Integritas Individu dan Masyarakat. Mantiq.

Rahman, F. (2019, February). Save the world versus man-made disaster: A cultural perspective. In IOP Conference Series: Earth and Environmental Science (Vol. 235, No. 1, p. 012071). IOP Publishing.

Sahib, H., Rahman, F., Duli, A., \& Asba, A. R. (2019, May). Customary Forest Conservation through Informal Knowledge System of Ammatowa Community. In IOP Conference Series: Earth and Environmental Science (Vol. 270, No. 1, p. 012042). IOP Publishing.

Saleh, N. J., Yassi, A. H., \& Rahman, F. (2021). Strategy of Apology in Buginese: A Sociolinguistic Study. ELS Journal on Interdisciplinary Studies in Humanities, 4(2), 188-196.

Suhasran, S. (2018). Pola Kerukunan Umat Beragama di Kabupaten Soppeng. A/Adyan, 5(103-134).

Tuasalamony, K., Hatuwe, R. S. M., Susiati, SusiatiMasniati, A., \& Nilawati, M. R. (2020). Pengembangan Pendidikan Karakter Di Sekolah Dasar Negeri 5 Namlea. Pedagogy, 7(2), 81-91. 